\title{
Shallow Groundwater Dynamics Controlled by Lisse and Re- verse Wieringermeer Effects
}

\author{
Tsuyoshi Miyazaki , Mohamed Khaled Ibrahimi, and Taku Nishimura
}

Department of Biological and Environmental Engineering, Graduate School of Agricultural and Life Sciences, The University of Tokyo, 1-1-1 Yayoi, Bunkyo-ku, Tokyo, 113-8657, Japan

Received: June 6, 2011 / Accepted: December 18, 2011

\begin{abstract}
This paper reviews research on the causes and effects of rapid shallow groundwater dynamics in response to recharge events and their contribution to soil salinization in arid and semi-arid areas. It identifies some of the major research questions which should answered for a better understanding and consequently a successful management and sustainability of these valuable resources. First, we give an overview of shallow groundwater systems with an emphasis on the rapid and disproportionate response of shallow water tables to recharge events. In this context, we highlight the two major phenomena responsible for such behavior, namely the Lisse Effect (LE) and the Reverse Wieringermeer Effect (RWE). The LE occurs when water infiltration caused by intense rain seals the surface soil layer to airflow, trapping and compressing air under pressure in the unsaturated zone. The RWE, as was usually defined, occurs wherever the capillary fringe is close to the ground surface. We believe that RWE also occurs in cases with a certain unsaturated zone over the capillary fringe and in response to sub-surface lateral inflow. This work also discusses the causes and potential effects of rapid water table rise in Metouia Oasis, South Tunisia, where the occurrence of rapid water table rises and soil surface salt accumulation, are presented. In Metovia Oasis, a highly dynamic saline shallow groundwater coupled with an arid climate characterized by high evaporation and low precipitation led to a soil salinization problem which is currently threatening the sustainable development of agriculture in the Oasis.
\end{abstract}

Key words: shallow groundwater, reverse Wieringermeer effect, Lisse effect, salinization.

* Corresponding authors: amiyat@soil.en.a.u-tokyo.ac.jp

\section{Introduction}

The Intergovernmental Panel on Climate Change (IPCC) reported in 2007 that water resource is becoming scarce. Thereafter, global water crisis has been discussed mainly in terms of water shortage. In addition to water shortage crisis, however, excess water crisis also is another issue to be solved especially in arid and semi-arid areas, where both water shortage caused by excess groundwater use and shallow groundwater formation caused by excess irrigation, threaten crop productions and lives of residents. It should be noticed that irrigation induced shallow groundwater rise, occasionally resulting in water logging, have caused soil salinization under dry climates. Understanding shallow groundwater behavior represents a fundamental prerequisite to predict and control salt accumulation in these areas.

Shallow groundwater systems (SGS), found in many regions in the world, have been recognized to have mutual relationships with a broad variety of systems and resource management issues, including forestry (Heuperman, 1999; Bliss and Comerford, 2002), environment (Westbrook et al., 2005), ecosystem (Minh et al., 1998; Nachabe et al., 2004), climate research (Yuan et al., 2008), management of water resources (Abdul and Gillham, 1984; Jaber et al., 2006), crop water requirement (Zhang et al., 1999; Soppe and Ayars, 2003), and soil salinization (Oguchi et al., 2004; Northey et al., 2006; Xu et al., 2008).

One of the important shallow water table's properties, especially for hydrologists and hydrogeologists, is their interdependencies with overlying land and surface water. This topic was addressed by the XXV Congress of IAH, 1994. The theme of that meeting was "Management to Sustain Shallow Groundwater Systems". Selected papers from that congress were published in a book edited by Dillon and Simmers (1998). In the opening review paper "Shallow groundwater systems" of this 
book, Townley (1998), after summarizing discussions, both on surface water-groundwater interaction and on flow and solute transport models, concluded that most of the processes involved in the movement of water and contaminants in shallow aquifers are probably well understood, for most practical purposes, but there will always be issues that require further investigations, especially when coupled physical, chemical and biological processes are involved, and also where the local characteristics of soils, vegetation and climate make the hydrology of the region apparently different from other areas which are well understood.

The question that arises with respect to shallow water table's properties is on their fluctuation in response to recharge and discharge phenomena. In this context, many researchers reported an important phenomenon observed in SGS; the disproportionate water table rise in response to rainfall events (e.g. O'Brien, 1982; Gillham, 1984; Abdul and Gillham, 1989). They showed that shallow water tables can often rise disproportionately compared to the volume of infiltrated water. Kayane and Kaihotsu (1988) have confirmed these observations noting that the rise in the water table in response to rainfall or irrigation is frequently much greater than would be predicted on the basis of water balance calculations using fillable porosity and net groundwater recharge. More recently, Hogervorst et al. (2003) reported that the groundwater level at depths between one and two meters in sandy soils without macropores can rise within hours after rainfall, much faster than predicted by models based on the standard Richards equation. Moreover, Jaber et al. (2006) studied water table response under shallow groundwater conditions in southwest Florida. They noted that a water table rise of 6.71 $\mathrm{cm}$ to a $0.16 \mathrm{~cm}$ rainfall event which is unexpectedly high. They added that the $6.71 \mathrm{~cm}$ of water table rise multiplied by a typical specific yield of 0.22 for the sandy soil of their study would result in $1.5 \mathrm{~cm}$ of recharge water compared with the $0.16 \mathrm{~cm}$ of rain that actually occurred during the storm.

\section{Causes of the Rapid Water Table Response to Re- charge Events}

Fluctuations and trends in the groundwater level are the result of a number of natural and artificial causes (Van Geer, 1987). Groundwater was reported to fluctuate in response to barometric pressure (Balugani and Antonellini, 2011), earth tide (Inkenbrandt et al., 2005), ocean tide (Gregg, 1966), earthquakes (Parker and Stringfield, 1950), precipitation (Fan et al. 1997; Leduc et al., 1997; Park and Parker, 2008; Rodríguez et al., 2011 ), irrigation (Forkutsa et al., 2009), and snow-melt (Rosenberry and Winter, 1997). Some authors even reported groundwater responses to nearby traffic, e.g., movement of trains and heavy trucks (Parker and Stringfield, 1950). Turk (1975) determined additional mechanisms for the high frequency fluctuations including temperature-induced air volume and surface tension changes. He explained that as temperature increases, the volumetric air content can be increased due to thermal expansion of trapped air, resulting in a rise of the water table when it is close to the land surface.
In the present review, we focus on the phenomena that induce rapid shallow water table responses to recharge events (precipitation, irrigation, snow-melt, etc...). The observed disproportionately large rise in the water-table in response to recharge events has been often attributed, in the absence of preferential flow, to one of the two major phenomena: the Lisse effect, LE (Heliotis and DeWitt, 1988; Weeks, 2002) and the reverse Wieringermeer effect, RWE (Gillham, 1984; Novakowski and Gillham, 1988; Horn, 2006). Both phenomena are reviewed in the next section.

Prior to explaining the physical basis of the LE and the RWE, it is necessary to define the relevant terminology. The air entry value is defined as the pressure head of the pore water where air begins to displace water, as evidenced by the first decrease in water content in the water retention curve (Sophocleous, 1985). The Capillary fringe or zone of tension saturation is the nearly saturated region immediately above the water table which extends from zero water pressure head to approximately the air entry value (Gillham, 1984; Sophocleous, 1985). Soil texture and soil structure are the major factors controlling the thickness of capillary fringe (Novakowski and Gillham, 1988). In case where the soil is uniform, the height of capillary fringe is equal to the air entry value of its water retention curve (e.g. Lu and Likos, 2004). The specific yield of a porous material is the ratio of the volume of water which, after being saturated, it will yield by gravity, to its own volume (Healy and Cook, 2002). It was demonstrated either through numerical studies (Sophocleous, 1985), or laboratory as well as field investigations (Jaber et al., 2006), that the estimation of water table responses to recharge events based on ultimate specific yield, which can be estimated from an equilibrium soil water profile (Sophocleous, 1985), is erroneous and always underestimates the rate and total amount of water table rise especially in shallow water table environments. Therefore, the concept of "variable specific yield" was introduced. Likewise, Gillham (1984) pointed out that the shallow water table response to added water could be explained by considering the specific yield above a shallow water table to be variable, with values decreasing as the water table approaches ground surface. This phenomenon, according to Gillham (1984), is related to the shape of the water content profile above the water table and its potential significance is determined by the water content-pressure head relation for the particular geologic material.

\section{The Lisse Effect}

The Lisse effect was first noted and explained by Thal Larsen in 1932 from water-level observations obtained in wells located in the garden of horticultural school in the village of Lisse, Holland (Weeks, 2002). The LE was shown to occur when infiltration caused by intense rain seals the surface soil layer to airflow, trapping and compressing air under pressure in the unsaturated zone (Urie, 1977; Heliotis and DeWitt, 1987; Weeks, 2002). As Weeks (2002) pointed out, the LE results in a very rapid water-level rise in the well, despite the fact that the water table is essentially unaffected, with a water-level recession lasting for several hours to few days. Hence, the LE attributes the dispro- 
portionate water table rise to air entrapment and an increase in the gas pressure above the capillary fringe during infiltration. The infiltrating rain acts as a tightly closing lid, which results in the water table rising to the level required to compensate for the pressure increase (Heliotis and DeWitt, 1987, Guo et al., 2008). In this context, Kayane and Kaihotsu (1988) mentioned the consequence build-up of a pneumatic potential following the infiltration at a high rate of rainfall or flooding water into the soil due to entrapped air in the soil between the downwardmoving wetting front and the water table. Similarly, Miyazawa (1976) reported field observations in a flat upland which provide a clear evidence of the pneumatic effect on the water table changes. Furthermore, Fayer and Hillel (1986) carried out laboratory as well as field investigations of air encapsulation phenomenon and determined that part of the large and rapid rise of shallow water tables during infiltration may be the result of air encapsulation. They simulated the effect of infiltrating water on water table when air was and was not encapsulated, and they found that the water table rose two to five times higher and more rapidly in the profile when air was encapsulated than when it was not. They added that the shallower the water table was, the more pronounced the effect.

For several decades, the LE has been explained as being caused by the compression of air ahead of an advancing wetting front that results in elevated unsaturated zone gas pressure relative to the atmospheric pressure (Figure 1). In 2002, Weeks revisited the LE phenomenon and completed this explanation by considering the effect of the confined air pressure on movement of the wetting front. He further explained that such a consideration leads to the conclusion that the confined air pressure is a function of the pressure head of water held just beneath the wetting front. Recently, Guo et al. (2008) presented a threedimensional numerical model to test the LE theory as presented by Weeks (2002). They found that Weeks's theory results do not completely conform to the results of their complicated model. The reason of this discrepancy according to these authors is the occurrence of escaped air which was considered in the simulation but ignored in Weeks's theory of LE. Additionally, Zhang et al. (2011) conducted numerical modeling of shallow water table behavior with LE using two numerical models: IHM (Integrated Hydrologic Model) and HYDRUS-1D (single phase, one-dimensional Richard's equation model). They pointed out that the two models failed to reproduce the observed depth of groundwater mainly due to lack of consideration of air entrapment effect. It is thus critical to incorporate air entrapment in prediction models for better modeling of shallow water table behavior under LE conditions.

The LE was noted by many researchers both at field as well as at laboratory scales. For instance, Urie (1977) recorded the occurrences of the LE in shallow water tables (depths between 0.6 and $1.5 \mathrm{~m}$ ) in the Udell Experimental Forest (Manistee, Michigan, USA). In this study, the hydrologic measurements lasted for 10 years and were made under jack pine and red pine plantations and under native hardwood forests typical of these sandy outwash plains. Urie (1977) pointed out that this LE creates a problem of separating the well response due to percolating rainfall, which recharges the saturated zone. De Zang (1981) observed exceptionally high fluctuations of groundwater during rainfall at the Dutch island of Schiermonnikoog. He attributed such fluctuations to the LE phenomenon which implies that the phreatic level can rise rapidly due to an increased pressure of the soil air above the capillary fringe. The increase of the pressure is caused here by the capillary infiltration of rainwater in the soil. De Zang (1981) added that at Schiermonnikoog the depth of wetting front and the extent of groundwater rise were determined by the thickness of a semipervious layer at the surface with strong capillary tension.

\section{The Reverse Wieringermeer Effect}

The term "Wieringermeer effect" was first used by Hooghoudt (1947, cited by Gillham, 1984) to refer to the rapid de-

Table 1. Main characteristics of the Lisse Effect and the Reverse Wieringermeer Effect.

\begin{tabular}{|c|c|}
\hline Lisse Effect & Reverse Wieringermeer Effect \\
\hline $\begin{array}{l}\text { First noted by Thal Larsen (1932), in the village of Lisse, } \\
\text { Holland }\end{array}$ & $\begin{array}{l}\text { Hooghoudt (1947) used "Wieringermeer effect" to refer to } \\
\text { the rapid decline of water table in Wieringermeer polder } \\
\text { in Holland. }\end{array}$ \\
\hline $\begin{array}{l}\text { Depth to water table larger than the capillary fringe } \\
\text { height }\end{array}$ & $\begin{array}{l}\text { The capillary fringe extends from the water table to almost } \\
\text { the ground surface }\end{array}$ \\
\hline $\begin{array}{l}\text { Sharp rise in water level followed by slow recession } \\
\text { lasting several hours to few days }\end{array}$ & $\begin{array}{l}\text { Sharp rise in water level followed by an equally sharp } \\
\text { decline }\end{array}$ \\
\hline Occurs only during high intensity rains & May be triggered by gentle as well as intense rains \\
\hline $\begin{array}{l}\text { Occurs in a fully penetrating well tapping the water } \\
\text { table, however the actual water table level is not } \\
\text { affected }\end{array}$ & $\begin{array}{l}\text { Occurs equally in both a fully penetrating well tapping the } \\
\text { water table and in the water table level }\end{array}$ \\
\hline $\begin{array}{l}\text { Water table rises to the level required to compensate } \\
\text { for the pressure increase }\end{array}$ & Water table rises usually to soil surface \\
\hline
\end{tabular}


Figure 1. The conditions of the Lisse effect occurrence. CF: capillary fringe; $m$ : depth of infiltrated water following an intense rain; $\Delta \mathrm{H}$ : water level rise in the observation well resulting from sharp wetting front during intense rain trapping air and increasing soil air pressure.

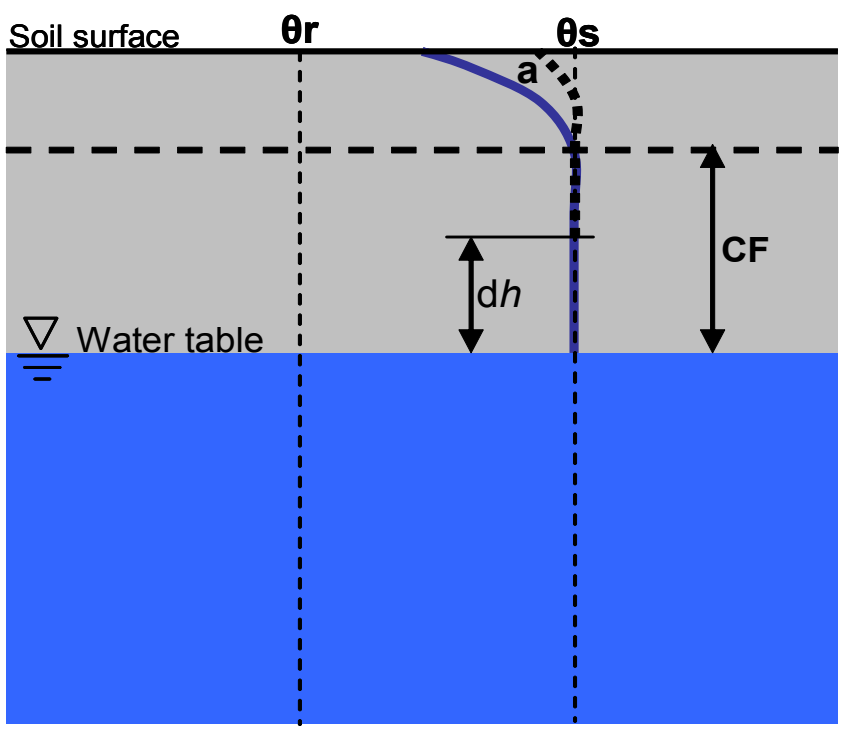

Figure 2. The conditions of the Reverse Wieringermeer effect occurrence. CF: capillary fringe; $\theta$ r: residual water content; $\theta$ s: saturated water content; dh: water table rise; a: water recharge.

cline of groundwater level that he observed in the Wieringermeer polder in Holland. The inverse phenomenon (i.e. rapid rise of groundwater) has been referred to as the "reverse Wieringermeer effect" (Gillham, 1984). This mechanism deals with the case where the capillary fringe extends from the water table almost to the ground surface. In this case the addition of a very small amount of water would fill the air filled pores at the capillary fringe. The effect is of similar magnitude to, but of different origin than the Lisse effect. Table 1 summarizes the main characteristics of each phenomenon.

Gillham (1984) registered a water table rise of about 30 $\mathrm{cm}$ in $0.25 \mathrm{~min}$ in response to the addition of $0.3 \mathrm{~cm}$ of water during laboratory experiments. He explained such rapid and disproportionate shallow water table response to added water by considering the specific yield and the capillary fringe concepts. He pointed out that the values of specific yield decrease as the water table approaches ground surface, and suggested that the capillary fringe could contribute to the rapid groundwater response to precipitation. Gillham (1984) speculated that in the case where the capillary fringe extends from the water table to the ground surface, the specific yield is close to zero and the application of a small amount of water will result in a rapid and large rise in groundwater. Heliotis and Dewitt (1987) have confirmed Gillham's observations noting that in the RWE the capillary fringe extends to land surface, and only a small amount of rain is required to fill the capillary menisci and bring both the water table and the water level in the well to near land surface. They further noted that the RWE may be triggered by gentle as well as intense rains and is characterized by a sharp rise in water level, followed by an equally sharp decline. Similarly, Kim and Bierkens (1995) indicated that a phreatic surface at a depth beneath the surface equal to the air entry value of the porous medium would need an infinitely small amount of water to change the pressure in the tension saturated zone from less than atmospheric to greater than atmospheric. This would result in an instantaneous rise of the phreatic surface. Brutsaert (2005) indicated that for most soils within the nearly saturated capillary fringe, a small change in water content can result in a relatively large change in pore water pressure. He further postulated that based on this fact, the addition of a very small amount of water to a relatively moist soil can raise the water table rapidly, almost as a pressure wave type of propagation, to produce a saturated soil profile.

Figure 2 depicts the hypothetical moisture profiles above a rising shallow water table. After a change of water level, the water table will rise by dh to a new level. The area a represents the volume of water per unit area that is added to storage due to the water-level rise. In order to explain the physical basis of RWE, Healy and Cook (2002) reasoned that in the case of a shallow groundwater the capillary fringe is close to the soil surface and the water table depth is not great enough to allow moisture content at land surface to reach the value of residual moisture content (Figure 2). In this case, the area a representing the water yield is less than Sydh. The discrepancy between actual yield and that calculated on knowledge of Sy and dh has been observed to increase as depth to water table decreases (e.g. Gillham, 1984, Sophocleous, 1985, Healy and Cook, 2002). This phenomenon is reflected by a nearly instantaneous rise in water level in response to only a small amount of infiltration.

The RWE has been shown by numerous researchers to occur in a variety of shallow water table environments (Table 2). Novakowski and Gillham (1988) have conducted field investigations of the nature of water table response to precipitation in shallow water table environments. Several water table response tests were performed in undulating topography at a field site near Chalk River, Ontario. The tests were performed by apply- 
Table 2. The reverse Wieringermeer effect (RWE) reported by some workers in field and laboratory conditions.

\begin{tabular}{|c|c|c|c|}
\hline Reference & Study & Location & Soil type \\
\hline & Condition & & \\
\hline Kaihotsu and Tanaka (1982) & Field & $\begin{array}{l}\text { Yatabe near Tsukuba Academic New Town, } \\
\text { Japan }\end{array}$ & Kanto loam \\
\hline Abdul and Gillham (1984) & $\begin{array}{l}\text { Laboratory } \\
\text { experiment }\end{array}$ & Laboratory & Medium-fine sand \\
\hline Gillham (1984) & Field test & Flat sandy area at Borden, Ontario, USA & Sand \\
\hline Heliotis and DeWitt (1988) & $\begin{array}{l}\text { Field and } \\
\text { Laboratory }\end{array}$ & Northwestern lower Michigan, USA & $\begin{array}{l}\text { Peatland, Large peat } \\
\text { cores }\end{array}$ \\
\hline Turner and Nielsen (1997) & Field: beach & US Atlantic coast & Beach sand \\
\hline Drabsch et al. (1999) & Field & Estuarine intertidal sand flat, New Zealand & Fine sand \\
\hline Jaber et al. (2006) & Lysimeter & Florida, USA & Sandy soil \\
\hline Shilling (2007) & Field study & Walnut Creek watershed, lowa, USA & $\begin{array}{l}\text { Silt loam to loam, } \\
\text { Silty clay loam }\end{array}$ \\
\hline
\end{tabular}

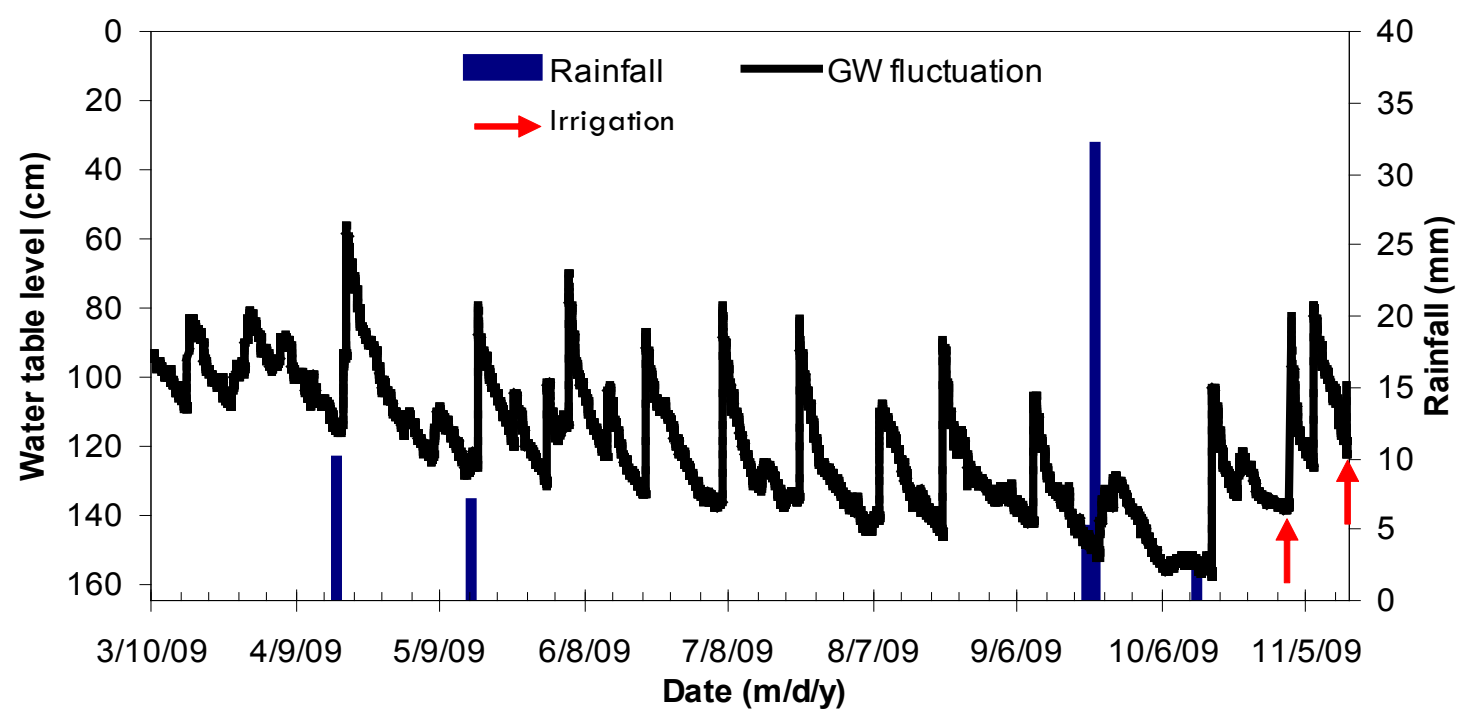

Figure 3. Observed shallow groundwater fluctuations in Metouia Oasis from March to November 2009. Water table levels were recorded at 30 min intervals (after lbrahimi et al., 2010).

ing simulated rainfall to a study site instrumented in detail with porous membrane tensiometers. Changes in hydraulic head were measured using a pressure transducer and a hydraulic switch. Results showed a disproportionate rise in water table in areas where the zone of tension saturation (capillary fringe) extended to ground surface. Novakowski and Gillham (1988) reported a rise of about $13 \mathrm{~cm}$ of the water table in the lowest lying areas for rainfall of only $5 \mathrm{~mm}$ over a duration of $5.3 \mathrm{~min}$. In the area of higher elevation, the rise was only $5 \mathrm{~cm}$ for the same rainfall amount. They concluded that the magnitude of the response in the low-lying area can only be explained by the presence of the capillary fringe.

The RWE phenomenon was also reported by a number of researchers focusing on beach studies (Turner and Nielsen, 1997; Cartwright et al., 2006; Horn, 2006). For instance, Turner and Nielsen (1997) noted that the rapid and disproportionate rise of the water table within the swash zone results from the special case situation of the upper extent of the capillary fringe coinciding with the sand surface. These authors further explain that the amount of water required to cause the water table to rise to the sand surface is in the order of a grain diameter (less than $1 \mathrm{~mm}$ for beach sands), in comparison to the change in water table elevation, which is on the order of the height of the capillary fringe. This was substantiated by the research of Cartwright et al. (2006) who showed that in the case of an extending of moisture to the sand surface in a sandy beach, for the loss (or gain) of an amount of water of the order less than a grain diameter the pressure may fluctuate up to the order of a capillary fringe height. These authors used the RWE to refer to this phenomenon. The disproportionate and rapid water table rise in response to added water event was observed in playas and sabkhat systems (Tyler et al., 2006). In their review paper summarizing the 
dynamics of water tables beneath playas and sabkhat, Tyler et al. (2006) noted that in cases where the water table is very close to the land surface, small precipitation events or slight changes in evaporation rate can cause the water table to rapidly rise to the land surface and inundate the playa. They further mentioned that rapid response of water tables to direct infiltration has been well explained however the corollary, i.e., what will be the response of a water table to changes in evaporation demand, is less well documented.

\section{Discussion}

Thanks to the numerous researchers who investigated the rapid shallow water table response to recharge events, this previously called anomalous phenomenon is being currently, to some extent, more evident. However, despite this huge effort, many related aspects remain to be clarified and require further investigation. Likewise, there are many unsolved or partially solved questions such as: (i) Does the RWE occur in response to subsurface recharge (i.e. without rainfall or irrigation at the site), and if it does, in which conditions? In fact, in many hydrogeological environments, water table has been shown to rise during rainless periods owing to lateral subsurface groundwater inflow (Li et al., 2008; Wang et al., 2009; Ibrahimi et al., 2010), (ii) What is the effect of soil type, water table level and recharge volume on the RWE and the LE phenomena? (iii) Is it possible to simulate groundwater response under RWE or LE conditions? Furthermore, there is very little information available on the possible effects of these phenomena. Thus, more clarification is needed regarding their hydrological, environmental and agricultural implications, if any.

In the following, we will be discussing some of these aspects. Specifically, the possible extension of the RWE concept and the potential effects of the rapid and high shallow water table rise with emphasis on soil salinization risk.

\section{Need of an Extension of the RWE Concept}

In case where the top of unsaturated capillary zone does not extend to ground surface, Kayane and Kaihotsu (1988) noted that the water table response due to mass flow through porous media would be recognized when the wetting front reaches the top of unsaturated capillary zone. Ibrahimi et al. (2011) conducted laboratory experiments to study shallow groundwater response to recharge events using one dimensional columns filled with sandy (Toyoura sand, TS) and clayey (Chiba light caly, CLC) soils. They showed that groundwater exhibited a RWE response type to water input when water table was initially set at shallow depths of $20 \mathrm{~cm}$ and $15 \mathrm{~cm}$ in the case of TS and CLC, respectively. This phenomenon was reflected by a rapid and large water table rise in response to a small volume of added water. In fact, a water table rise of about $120 \mathrm{~mm}$, and $50 \mathrm{~mm}$ was observed in response to $1 \mathrm{~mm}$ rainfall in TS and CLC, respectively. For deeper levels $(40 \mathrm{~cm}$ in the case of TS, $30 \mathrm{~cm}$ in the case of $\mathrm{CLC}$ ) they found also a disproportionate groundwater response but with lower magnitude and higher time response compared to shallow depths. Based on these findings it seems likely that the RWE, which was usually considered to occur in response to surface recharge and for groundwater level less than the capillary fringe height, can occur in response to lateral subsurface recharge and for groundwater levels exceeding the capillary fringe height. This leads to the question on whether we need to extend the RWE concept to account for these cases. These laboratory observations were supported by a field study conducted by Ibrahimi et al. (2010) in Metouia Oasis (South East Tunisia; 33०58'00.1 2"N-10000'02.55"E) where a high frequency based assessment of shallow water table was carried out. Figure 3 provides their detailed data of shallow groundwater fluctuations in Metouia Oasis obtained using high resolution water table monitoring over a period of 250 days (Ibrahimi et al., 2010). It reveals a very dynamic behavior with highly complex and transient fluctuations. This behavior was the consequence of climatic conditions as well as of several hydrological processes taking place in the observation site and in the upstream areas. During 2009, total rainfall was $147 \mathrm{~mm}$ which was similar to the longterm average $(146 \mathrm{~mm} / \mathrm{y})$ in Metouia Oasis. The question here is how the annual precipitation of about $15 \mathrm{~cm}$ water depth can cause the frequent fluctuation of groundwater between $60 \mathrm{~cm}$ and $150 \mathrm{~cm}$ below the surface? Ibrahimi et al. (2010) analyzed this result and concluded that these frequent groundwater fluctuations are attributed to the RWE. They reasoned that the water table rise was not only observed during rainfall but also during rainless periods and with no irrigation at the observation site and was mainly due to water inflow from surrounding irrigated area. In this condition the occurrence of an advancing infiltration front (a major condition for LE occurrence) is unlikely. Both natural rainfalls and irrigation activities in the neighboring areas close to the observation site are responsible for the RWE.

The above discussed laboratory and field results are implying the possible extension of RWE concept from the case where capillary fringe extends from the water table almost to the ground surface to the case where capillary fringe remains within the subsurface zone over which the unsaturated soil zone is covering above. In this extended RWE, the addition of a very small amount of water would infiltrate into the unsaturated surface soil zone before filling the menisci of the capillary fringe. In other words, a sharp rise in water level, followed by an equally sharp decline, may be more or less in the extended RWE. However, the unsaturated vertical flow dynamics in the upper soil zone and subsequent quick responding flow dynamics in the capillary fringe zone where RWE is dominating is still vague and needs to be explained clearly.

\section{Effects of Rapid Water Table Fluctuations}

Although a wealth of information exists on the causes of rapid and large shallow groundwater fluctuations, comparatively little research has been conducted on their effects. Heliotis and DeWitt (1987) emphasized the environmental significance of such phenomenon. They quoted that a failure to recognize and account for rapid water table responses could lead to an overestimation of wastewater loading rates, flooding, and transport of wastewater into neighboring water bodies. In his study of the capillary fringe effects on the rapid shallow water table 
response to precipitations, Gillham (1984) emphasized the importance of considering the hydrological implications of such phenomenon. He discussed some examples including recharge and consumptive use calculations, streamflow generation, contaminant migration to surface waters and contaminant transport in shallow water table regimes. Among these hydrologic processes, Abdul and Gillham (1984, 1989) focused on the capillary fringe effects on streamflow generation. They showed through laboratory as well as field studies the significant role of the capillary fringe in stream flow generation under certain conditions. However, Cloke et al. (2006) showed numerically that for many riparian zones based on the Abdul and Gillham model, capillary fringe groundwater ridging does not produce the high proportions of pre-event water observed in the field.

With respect to solute movement following rapid water table response, questions regarding whether the rapid water table rise transports solutes to soil surface or not continue to challenge researchers at laboratory and field scales. For instance, in the case of a saline shallow water table undergoing RWE, the question arises as to whether its rapid and large response affects soil surface salt accumulation or not?

Based on the literature, it is difficult to draw definitive answer to these questions. On the one hand the studies dealing with the effect of shallow water table rapid rise on salt accumulation are very scarce. On the other hand, some of the existing few researches provided contradictory findings. Likewise, in the Harran Plain, south-eastern Turkey Çullu et al. (2010) observed significant seasonal variations in the salt dynamic with the fluctuation levels of the groundwater. This was not the case for soils with less water fluctuation which showed lower salt accumulation in the root zone. Additionally, after a thorough characterization of shallow groundwater fluctuation in Metouia Oasis (aforementioned), Ibrahimi et al. (2010) discussed the effect of such behavior on soil salinization which is becoming a major problem threatening the Oasis sustainability. They inferred that the frequent and rapid groundwater fluctuation seems to cause not only more salt to accumulate at soil surface but also an enhancement of the phenomenon. Figure 4 depicts soil salinity profile in an observation site located in the eastern part of the Metovia

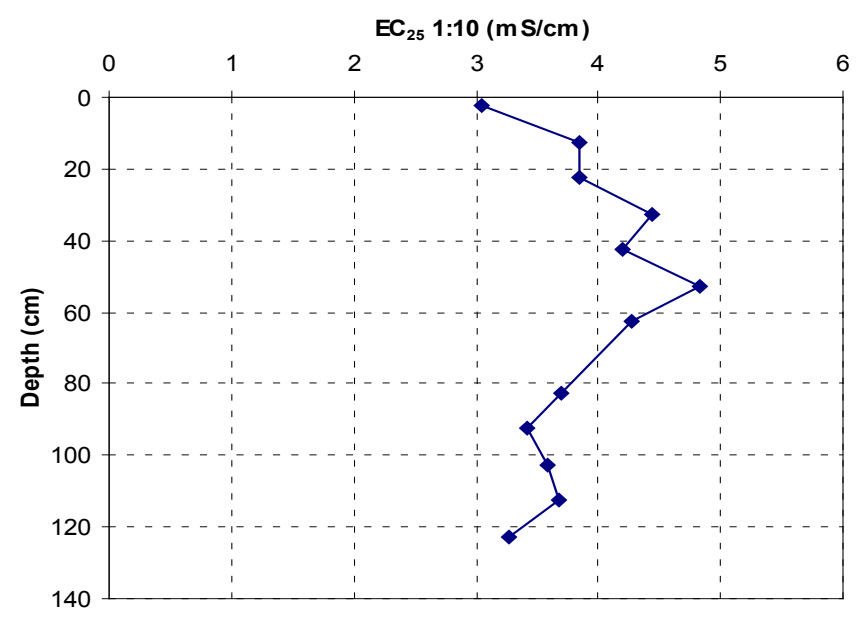

Figure 4. EC profile in the field of Metouia Oasis.
Oasis. It can be seen that the soil has high salinity values ranging between $3.1 \mathrm{dS} / \mathrm{m}$ to $4.9 \mathrm{dS} / \mathrm{m}(\mathrm{EC} 1: 10)$ throughout the soil profile. Salt accumulation has occurred at depths between $30 \mathrm{~cm}$ and $60 \mathrm{~cm}$. This soil salinity distribution is most likely the result of salt leaching from soil surface by irrigation water and water supply by capillary rise from saline shallow groundwater. The rainfall in Metouia oasis is too low to continuously play a significant role in leaching of accumulated salts (Ibrahimi et al., 2010). Another example of the potential contribution of groundwater rapid fluctuations to soil salinization was reported in the Songnen Plain, Northeast China (Wang et al., 2009). In this Plain many researches showed the major role of groundwater in soil salinization specifically in areas where water table level is shallow (below 2-2.5 m) (Qiang et al., 2009; Wang et al., 2009). For instance, Qiang et al. (2009) conducted a field experiment in the Da'an Sodic Land (southeast of Songnen Plain) in order to reveal the dynamics of the soil water and solute influenced by the shallow groundwater. They pointed out that the soil salt content was mainly controlled by the groundwater dynamics in the subsoil layer under $100 \mathrm{~cm}$ and decreased with the groundwater level receding. Chi and Wang (2010) stated that soil salinization in Songnen Plain is a result of upward movement and evapo-concentration of soluble salts present in the shallow groundwater. In opposition to the aforementioned studies in Harran Plain (Çullu et al., 2010), in Metouia Oasis (Ibrahimi et al., 2010) and in Songnen Plain (Qiang et al., 2009), Abit et al. (2008) reported different findings from their field evaluation of solute transport in the capillary fringe and shallow groundwater at the northeast end of Juniper bay in Robeson County, USA. They indicated that although there was a large and rapid water table rise, the $\mathrm{Br}$ plume did not move up. They reasoned that the upward movement of the water table is not generally produced by upward-moving water, but rather by down-ward moving water that enters air-filled pores in the CF.

\section{Conclusion}

This review addresses the rapid and disproportionate water table rise in response to recharge events observed in shallow groundwater systems. Specifically, the main causes and effects of this phenomenon are presented and discussed. Based on the reviewed literature, it was shown that shallow water tables can often rise rapidly and disproportionately compared to the volume of infiltrated water. The fast response time of shallow groundwater systems to hydrologic change was attributed to one of the two major phenomena, namely the Reverse Wieringermeer Effect and the Lisse Effect. The RWE was usually considered to occur in response to surface recharge and for groundwater level less than the capillary fringe height. However, a number of studies reported its occurrence in response to lateral subsurface recharge and for groundwater levels exceeding the capillary fringe height. Accordingly, we suggest the extension of this concept to account for these cases.

Although these phenomena were addressed by numerous studies, nevertheless a number of related aspects are poorly understood and still making the subject of scientific debate until this day. For instance, little research has been conducted on the 
effects of these phenomena in general and their contribution to solute movement in particular. In this context, while a number of studies showed the enhancement effect of shallow groundwater rapid fluctuation on soil salinization, some others found that this phenomenon has no contribution to salt accumulation at soil surface layers. Therefore, more research is needed to draw definitive conclusions on the effects of the rapid water table rise on solute movement from saturated to unsaturated zone. In order to address these questions researchers need to examine these phenomena more minutely, first at laboratory scale and then through field investigations. The current advancement of measurement tools can be of great help.

\section{Acknowledgements}

The research reported in this paper was supported in part by Grant-in Aid for Scientific Research (A) (Project 20248025), Japan. Gratitude is expressed to Bori Cedria Science and Technology Park, Republic of Tunisia, for their comprehensive supports to this research, to Professor Abdelkrim Charef and Professor Mitsuteru Irie for their helpful discussions with us during our field investigation in Tunisia, to Japan bank for International Cooperation $(J B I C)$ for the arrangements of this research project, to Asia SEED for their continuous supports, to President M. Nakajima of ARENA for his helpful supports, and to Mr. H. Imoto of The University of Tokyo for his effective supports to our experiments.

\section{References}

Abdul AS and RW Gillham (1984) Laboratory Studies of the Effects of the Capillary Fringe on Streamflow Generation. Water Resources Research 20: 691-698.

Abit SM, A Amoozegar, MJ Vepraskas, and CP Niewoehner (2008) Solute transport in the capillary fringe and shallow groundwater: field evaluation. Vadose Zone Journal 7: 890-898. DOI: 10.2136/ vzi2007.0102.

Balugani E and M Antonellini (2011) Barometric pressure influence on water table fluctuations in coastal aquifers of partially enclosed seas: An example from the Adriatic coast, Italy. Journal of Hydrology 400: 176-186.

Bliss C M and N B Comerford (2002) Forest Harvesting Influence on Water Table Dynamics in a Florida Flatwoods Landscape. Soil Science Society of America Journal 66: 1344-1349.

Brutsaert W (2005) Hydrology, An Introduction. Cambridge University Press, New York: 605p.

Cartwright N, TE Baldock, P Nielsen, DS Jeng and L Tao (2006) Swashaquifer interaction in the vicinity of the water table exit point on a sandy beach. Journal of Geophysical Research 111:1-13. C09035, DOI: $10.1029 / 2005 J C 003149$

Chi CM and ZC Wang (2010) Characterizing salt-affected soils of Songnen Plain using saturated paste and 1:5 soil-to-water extraction methods. Arid Land Research and Management 24: 1-1 1. DOI: $10.1080 / 15324980903439362$

Cloke HL, MG Anderson, JJ McDonnell, and JP Renaud (2006) Using numerical modeling to evaluate the capillary fringe groundwater ridging hypothesis of streamflow generation. Journal of Hydrology 316: 141-162.

Çullu MA, S Aydemi, M Qadi, A Almaca, AR Ozturkmen, A Bilgic, and N Agca (2010)

Implication of groundwater fluctuation on the seasonal salt dynamic in the Harran plain, South-East Turkey. Irrigation and Drainage 59 (4): 465-476. DOI: 10.1002/ird.507.

Deng W, Y He, X Song, and B Yan (2001) Hydrochemical characteristics of salt marsh wetlands in western Songnen Plain. Journal of Geographical Sciences 11 (2): 217-223.

De Vries JJ and I Simmers (2002) Groundwater recharge: an overview of processes and challenges. Hydrogeology Journal 10:5-17. DOI 10.1007/s10040-001-0171-7.

De Zanger FAP (1981) Exceptional groundwater level fluctuations at the Dutch Island of Schiermonnikoog. Nordic Hydrology: 111-118.

Dillon P and I Simmers (1998). Shallow groundwater systems: IAH international contribution to hydrogeology 18. AA Balkema, Rotterdam: $240 \mathrm{p}$.

Drabsch JM, KE Parnell, TM Hume and TJ Dolphin (1999) The Capillary Fringe and the Water Table in an Intertidal Estuarine Sand Flat. Estuarine, Coastal and Shelf Science 48: 215-222

Fan Y, CJ Duffy and DS Oliver (1997) Density-driven groundwater flow in closed desert basins: Field investigations and numerical experiments. Journal of Hydrology 196 (1-4): 139-184.

Fayer MJ and D Hillel (1986) Air encapsulation, I, Measurment in a field soil. Soil Science Society of America Journal 50 (3): 568-572.

Forkutsa I, R Sommer, YI Shirokova, JPA Lamers, K Kienzler, B Tischbein, C Martius, PLG Vlek (2009) Modeling irrigated cotton with shallow groundwater in the Aral Sea Basin of Uzbekistan: I. Water dynamics. Irrigation Science 27:331-346. DOI 10.1007/s00271009-0148-1

Fretwell BA, WG Burgess, JA Barker, NL Jefferies (2005) Redistribution of contaminants by a fluctuating water table in a micro-porous, double-porosity aquifer: Field observations and model simulations. Journal of Contaminant Hydrology 78: 27-52.

Gillham RW (1984) The capillary fringe and its effect on water table response. Journal of Hydrology 67: 307-324.

Gregg DO (1966) An analysis of groundwater fluctuations caused by ocean tides in Glynn county, Georgia. Groundwater 4 (3): 24-32.

Guo HP, JJ Jiao, and EP Weeks (2008) Rain-induced subsurface airfow and Lisse effect. Water Resources Research 44(7): W07409. doi: 10.1029/2007WR006294

Healy RW and PG Cook (2002) Using groundwater levels to estimate recharge. Hydrogeology Journal 10:91-109. DOI 10.1007/ s10040-001-0178-0

Heliotis FD and CB DeWitt (1987) Rapid water table responses to rainfall in a Northern peatland ecosystem. Water Resources Bulletin 23 (6): $1011-1016$.

Heuperman A (1999) Hydraulic gradient reversal by trees in shallow water table areas and repercussions for the sustainability of treegrowing systems. Agricultural Water Management 39: 153-167.

Hogervorst FAN, GH de Rooij, and MFP Bierkens (2003) Rapid rise after rainfall of a shallow groundwater table in a sandy soil: comparing simulations to observations. Geophysical Research Abstracts 5: 03495. European Geophysical Society.

Horn DP (2006) Measurements and modeling of beach groundwater flow in the swash-zone: a review. Continental Shelf Research 26: 622-652

Ibrahimi MK, T Miyazaki, and T Nishimura (2010) A high measurement frequency based assessment of shallow groundwater fluctuations in Metouia Oasis, South Tunisia. Hydrological Research Letters 4: 7579. DOI: $10.3178 /$ HRL.4.75

Ibrahimi MK, T Miyazaki, K Nishikawa, T Nishimura, and H Imoto (2011) Experimental and modeling investigations of shallow water table fluctuations in relation to Reverse Wieringermeer Effect. Open Journal of Soil Science 1: 17- 24.

Inkenbrandt PC, PK Doss, TJ Pickett, and RJ Brown (2005) Barometric and earth tide induced water level changes in the Inglefield sand- 
stone in southwestern Indiana. Proceedings of the Indiana Academy of Science 1 14(1):1-8

IPCC (2007) Contribution of Working Group III to the Fourth Assessment Report of the Intergovernmental Panel on Climate Change, 2007. Metz B, OR Davidson, PR Bosch, R Dave, LA Meyer (eds). Cambridge University Press. Cambridge, United Kingdom and New York, NY, USA. $851 \mathrm{p}$.

Jaber FH, S Shukla, and S Srivastava (2006) Recharge, upflux and water table response for shallow water table conditions in southwest Florida. Hydrological Processes 20: 1895-1907.

Kaihotsu I and T Tanaka (1982) Mechanism of vertical water movement in Kanto Loam during and after rainfall. Improvements of Methods of Long Term Prediction of Variations in Groundwater Resources and Regimes Due to Human Activity. Proceedings of the Exeter Symposium, July 1982. IAHS Publications 136: 169-177.

Kayane I and I Kaihotsu (1988) Some experimental results concerning rapid water table response to surface phenomena. Journal of $\mathrm{Hy}-$ drology 102: 215-234.

Kim CP and MFP Bierkens (1995) A formula for computation of timevarying recharge of groundwater - Comment. Journal of Hydrology 171: 191-193

Leduc C, J Bromley, P Schroeter (1997) Water table fluctuation and recharge in semi-arid climate: some results of the HAPEX-Sahel hydrodynamic survey (Niger). Journal of Hydrology 188-189: 123-138

Li F, G Pan, C Tang, Q Zhang and J Yu (2008) Recharge source and hydrogeochemical evolution of shallow groundwater in a complex alluvial fan system, southwest of North China Plain. Environmental Geology 55: 1109-1 122. DOI 10.1007/s00254-007-1059-1

Lu N and WJ Likos (2004) Rate of Capillary Rise in Soil. Journal of Geotechnical and Geoenvironmental Engineering 130 (6): 646-650 DOI: $10.1061 / \sim$ ASCE! 1090-0241 2004!130:6 646!

Minh LQ, TP Tuong, MEF van Mensvoort, and J Bouma (1998) Soil and water table management effects on aluminum dynamics in an acid sulphate soil in Vietnam. Agriculture, Ecosystems and Environment 68: 255-262

Miyazawa T (1976) Rapid rise of the water table after a heavy rainfall. Bungaku-ronso, Aichi Univ. 565 7: 585 - 606 (in Japanese).

Nachabe M, C Masek and J Obeysekera (2004) Observations and modeling of profile soil water storage above a shallow water table. Soil Science Society of America Journal 68: 719-724.

Northey JE, EW Christen, JE Ayars, and J Jankowski (2006) Occurrence and measurement of salinity stratification in shallow groundwater in the Murrumbidgee Irrigation Area, south-eastern Australia. Agricultural Water Management 81: 23-40.

Novakowski K and RW Gillham (1988) Field investigation of the nature of water table response to precipitation in shallow water table environments. Journal of Hydrology 97: 23-32

O'Brien AL (1982) Rapid water table rise. Journal of the American Water Resources Association 18 (4): 713-715.

Oguchi CT, T Hatta, and S Nemoto (2004) Experimental study on salt accumulation in soils for sustainable agriculture in arid developing areas. Geophysical Research Abstracts 6: 02551. European Geosciences Union 2004.

Park E, and JC Parker (2008) A simple model for water table fluctuations in response to precipitation. Journal of Hydrology 356: 344349.

Parker GG and VT Stringfield (1950) Effects of earthquakes, trains, tides, winds and atmospheric pressure changes on water in the geologic formations of southern Florida. Economic Geology 45: 441460.

Qiang L, C Baoshan and Y Zhifeng (2009) Dynamics of the soil water and solute in the sodic saline soil in the Songnen Plain, China. Environmental Earth Science 59:837-845.
Qiong G, L Jiangdong and Z Huiying (1996) A dynamic landscape simulation model for the alkaline grasslands on Songnen Plain in northeast China. Landscape Ecology 11 (6): 339-349.

Rengasamy P (2006) World salinization with emphasis on Australia. Journal of Experimental Botany 57 (5): 1017-1023.

Rhoades JD (1996) Salinity: electrical conductivity and total dissolved solids. Methods of soil analysis. Part 3. Chemical Methods-SSSA Book Series no. 5: 417-435.

Rhoades JD, F Chanduvi and S Lesch (1999) Soil salinity assessment. Methods and interpretation of electrical conductivity measurements. FAO irrigation and drainage paper 57, Rome: $165 \mathrm{p}$.

Richards LA (1941) A pressure membrane extraction apparatus for soil solution. Soil Science 51: 337-386.

Rodríguez MR, J Benavente, FJ Alcalá, M Paracuellos (2011) Long-term water monitoring in two Mediterranean lagoons as an indicator of land-use changes and intense precipitation events (Adra, Southeastern Spain). Estuarine, Coastal and Shelf Science 91: 400-410.

Romano E and M Giudici (2009) On the use of meteorological data to assess the evaporation from a bare soil. Journal of Hydrology 372 : 30-40. doi:10.1016/i.jhydrol.2009.04.003

Rosenberry DO and TC Winter (1997) Dynamics of water-table fluctuations in an upland between two prairie-pothole wetlands in North Dakota. Journal of Hydrology 191: 266-289.

Schilling KE (2007) Water table fluctuations under three riparian land covers, lowa (USA). Hydrological Processes 21: 2415-2424. DOI: 10.1002/hyp.6393.

Sophocleous M (1985) The Role of specific yield in groundwater recharge estimations: a numerical study. Ground Water 23 (1): 52-58.

Soppe RWO and JE Ayars (2003) Characterizing ground water use by safflower using weighing lysimeters. Agricultural Water Management 60: 59-71.

Townley LR (1998) Shallow groundwater systems. In Shallow groundwater systems: IAH international contribution to hydrogeology 18. AA Balkema, Rotterdam: pp 3-11.

Turk LJ (1975) Diurnal fluctuations of water tables induced from atmospheric pressure changes. Journal of Hydrology 26 (1-2): 1-16.

Turner IL and P Nielsen (1997) Rapid water table fluctuations within the beach face: Implications for swash zone sediment mobility? Coastal Engineering 32: 45-59.

Tyler SW, Munoz JF and Wood WW (2006) The response of Playa and Sabkha hydraulics and mineralogy to climate forcing. Ground Water 44(3): 329-338.

Urie D H (1977) Groundwater differences on pine and hardwood forests of the Udell experimental forest in Michigan. USDA Forest Service. Research paper NC-1 45: 1-12.

Van Geer FC (1987) Detection of natural and artificial causes of groundwater fluctuations. Proceedings of the Vancouver Symposium, August 1987). IAHS Publications 168: 597-606.

Wang S, X Song, Q Wang, G Xiao, C Liu, and J Liu (2009) Shallow groundwater dynamics in North China Plain. Journal of Geographical Science 19: 175-188. DOI: 10.1007/s1 1442-009-0175-0

Weeks EP (2002) The Lisse effect revisited. Ground Water 40: 652 656. doi: $10.1111 /$ i.1745-6584.2002.tb02552.x.

Westbrook SJ, JL Rayner, GB Davis, TP Clement, PL Bjerg, and SJ Fisher (2005) Interaction between shallow groundwater, saline surface water and contaminant discharge at a seasonally and tidally forced estuarine boundary. Journal of Hydrology 302: 255-269.

Xu L, J Yang, Q Zhang, and H Niu (2008) Modeling water and salt transport in a soil-water-plant system under different groundwater tables. Water and Environment Journal 22: 265-273.

Yuan X, X Zhenghui, Z Jing, T Xiangjun and Y Zong-Liang (2008) Effects of water table dynamics on regional climate: $A$ case study over East Asian monsoon area. Journal of Geophysical Research 113 : 
D21 112. DOI: 10.1029/2008JD010180

Zhang L, WR Dawes, PG Slavich, WS Meyer, PJ Thorburn, DJ Smith, and GR Walker (1999) Growth and ground water uptake responses of Lucerne to changes in groundwater levels and salinity: lysimeter, isotope and modeling studies. Agricultural Water Management 39:
265-282.

Zhang J, H Gong, MA Ross, X LI and D Zhou (2011) Numerical Modeling of Shallow Water Table Behavior with Lisse Effect. Chinese Geographical Science 21(2): 249-256. DOI: 10.1007/s11769$011-0462-4$ 